\title{
Enzyme Production from Cassava Peels by Aspergillus Awamori Kt-11: The Making of Natural Sweetener from Several tubbers
}

\author{
Ruth Melliawati*, and Farida Rahman \\ Research Center for Biotechnology, Indonesian Institute of Sciences (LIPI), Indonesia
}

\begin{abstract}
The use of cassava (Manihot esculenta Crantz) peel for enzyme production has not been widely used. The purpose of this study was to produce complex amylase enzymes from cassava peel by A. awamori KT-11 and apply them in the manufacture of natural sweeteners. Enzyme production is carried out on red and white cassava peel. Media of cassava peel sterilized, inoculated with $1 \%$ A. awamori KT-11, incubated for 5 days, then dried at $50^{\circ} \mathrm{C}$ and mashed. Making sugar is done on cassava flour, sweet potato (Ipomoea batatas L), taro (Colocasia esculenta) and cocoyam (Xanthosoma sagittifolium) with different concentrations of 10\%, 15\%, 20\%, and 15\% and $20 \%$ enzyme concentrations. The hydrolysis process is carried out for 3 days at $60^{\circ} \mathrm{C}$. The enzyme activity in red cassava peel was 405,006 U/mL and white cassava peel was 321,239 U/ml. The sugar produced in cassava, taro, sweet potato, and Cocoyam was $101.38 \mathrm{mg} / \mathrm{mL}, 81.18 \mathrm{mg} / \mathrm{mL}, 55.929 \mathrm{mg} / \mathrm{mL}$, and 42.874 $\mathrm{mg} / \mathrm{mL}$, respectively. The results of TLC showed that cassava and taro sugar contain maltose, lactose and glucose, sweet potatoes contained glucose and dextrin and Cocoyam containing fructose. The sweetness level of sugar from cassava, taro, sweet potato and Cocoyam is 14 brix, 12 brix, 9 brix and 9 brix, respectively.
\end{abstract}

Keywords: Aspergillus awamori KT-11, amylase, tuber, sugar

*Corresponding author: Ruth Melliawati

Cibinong Science Center, Jl. Raya Bogor Km. 46, Cibinong 16911, Indonesia

Tel. +62-21-8754587, Fax. +62-21-87754588

E-mail. ruthmell2000@yahoo.com

\section{Introduction}

Indonesia is one of the tropical countries rich in resources microorganism, some of which can be used for the production of enzymes, such as Aspergillus sp., Rhizopus sp. and Trichoderma reesei, (Perwitasari et al., 2017). Group of mold Aspergillus sp. was the most dominant group in producing amylase enzymes for the hydrolysis of starch. Biotechnology Research Center has a collection of A. awamori KT-11 which have the potential lipolytic and that it has been used in several studies. The use of the enzyme amylase more interest because of the environmentally friendly solution which happens to be more specific and did not result in a distorted sense of the final product (Nangin \& Sutrisno, 2015). Enzymatic hydrolysis is essential for producing a monosaccharide or disaccharides from starch. The results of the hydrolysis of starch into sugars was later used as a natural sweetener alternative.
Indonesia is also one of an agricultural country with natural resources are very abundant. The abundant natural resources of this, yet many under utilized. Some of its commodity raw material is thus a superior product in another country, so according to Safitri (2014) exported more raw materials to other countries with a relatively low price. One of the commodities that have not been put to good use, namely tubers (Husna et al., 2013). The developed countries have long been utilizing food as processed products of high nutritional value and the economic has a large market opportunity.

The high content of carbohydrates in tubers makes one a very biological resource potential to be developed mainly in an effort to realize the national food resilience (Ambarsari et al., 2009). Types of tubers are very diverse, including cassava, sweet potato, taro, cocoyam, the tuber of potato tubers arrowroot, black and others In General, the sweetness of the tubers is obtained through a process of breaking down carbohydrates (starch) by the 
enzyme amylase into sugars. Sugar produced from the decomposition of glucose, sucrose, and fructose. This type of sugar is what determines the sweetness of each type of tuber. Sweetness on the tuber is correlated with the amount of sugar, especially reducing sugar such as glucose and fructose (Alkayyis \& Susanti, 2016).

Sugar is an important commodity for the people of Indonesia, especially for consumption and food processing. According to the Ministry of agriculture (2017), national sugar consumption in the years 2013 and 2014 were amounting to 5.6 million tonnes the year 2015 and 2016 were amounted to 5.8 million tonnes, while the year 2017 was amounting to 5.7 million tonnes. The current domestic sugar production is estimated to reach only 2.2 tons, while consumption is about 5.7 million tons for the year 2017, so additional required about 2.5-3 million tons of sugar imports per year (Ministry of Agriculture, 2017). This encourages the emergence of a variety of efforts to increase the production of natural sugars.One alternative that has been taken, namely the attempt to produce sugar from tubers by means of hydrolysis starch into sugar

Raw material for producing glucose is material containing polysaccharide, obtained from starch. Starch is a polymer with the chemical formula anhydrous monosaccharide $\left(\mathrm{C}_{6} \mathrm{H}_{10} \mathrm{O}_{5}\right)$, and with the main constituent amylosa and amylopectin (Johnson \& Padmaja, 2013). Glucose and fructose production can use tubers containing starch, such as cassava, sweet potatoes, taro, cocoyam and so on.

Starch hydrolysis was done in two ways, namely by using acid or enzymes of starch solvers. Enzymatic hydrolysis method preferred because the resulting product better is also safer to consume than acid hydrolysis.

Several studies on liquid sugar from tubers have been carried out, including the manufacture of liquid sugar from cassava (Permatasari, and Yulistiani. 2015., Sutamihardja et al., 2015., Madara et al., 2017), sugar from sweet potato flour (Robi'a \& Sutrisno, 2015., Mesah et al. 2016., Mahmudatussa'adah,2014., Wei et al. 2017), liquid sugar from cocoyam (Rejeki et al, 2017), liquid sugar from taro tuber starch (Putra et al., 2015., Wahidah, 2017). The research was conducted to obtain information and solutions in tackling food needs.

This study was conducted to produce the enzyme glucoamylase and a natural sweetener from cassava starch (Manihot esculenta), sweet potato (Ipomoea batatas), Cocoyam (Xanthosoma sagittifolium) and taro (Colocasia esculenta) and knowing the types of sugar contained in it, the research was done.

\section{Materials and Methods}

\section{Microorganism}

In this study using A. awamori KT-11 mold. This mold is a collection of Biotechnology Research Center that have the potential to be amylolotic. A awamori KT-11 was cultured on PDA media and incubated for 5 days at room temperature.

\section{Preparation of materials and media production}

The processing of flour bulbs beginning with how fresh tubers, peeled and washed, then cut into thin and then put in the oven at a temperature of $50^{\circ} \mathrm{C}$ during \pm 2 days. Dry tubers that are already mashed, filtered with filter $150 \mu \mathrm{m}$ so obtained bulbs flour.

Preparation of enzyme production media, performed by means of the cassava peel (the inside) cleaned then cut small. As many as 500 g cassava peel are put into a baking dish and add $10 \%$ water containing minerals $\left(\mathrm{K}_{2} \mathrm{HPO}_{4}\right.$ $1 \%, \mathrm{KH}_{2} \mathrm{PO}_{4} 1 \%$ and Ammonium Sulfate $2.5 \%$ ), then sterilized at $121^{\circ} \mathrm{C}$ for approximately 15 minutes.

\section{The production of the enzyme powder glukoamilase}

The production of the enzyme glucoamylase is done by culturing of $5 \mathrm{ml}$ suspense mold A. awamori KT-11 inoculated to the media cassava peel medium, stirred, covered paper and incubated for 5 days at room temperature. After that in dry in the oven at a temperature of $50^{\circ} \mathrm{C}$, crushed with a blender, strained and retrieved the powder enzyme glucoamylase.

\section{Extraction of glucoamylase enzyme}

The extraction of complex amylase enzymes was carried out by means of $10 \mathrm{~g}$ of enzyme powder added $50 \mathrm{~mL}$ of citratephosphate buffer $\mathrm{pH} 4.8$, then shaken with a 
magnetic stirer in the refrigeration chamber for \pm 2 hours. Centrifuged at $10000 \mathrm{rpm}$ at $4^{\circ} \mathrm{C}$ for 10 minutes. The filtrate obtained as an enzyme (crude enzyme) is ready for use.

\section{The assay of glukoamilase enzyme activity}

A total of 0.02 grams of starch was weighed, then $0.4 \mathrm{~mL}$ of citrate-phosphate buffer $\mathrm{pH} 4.8$ was added, then heated at $60^{\circ} \mathrm{C}$ until it became clear. The solution that has been clear is then put into thermolyne at $60^{\circ} \mathrm{C}$. A total of 0.1 enzyme solutions were put into the test tube, then incubated in thermolyne for 60 minutes, then heated in boiling water for about \pm 1 minute to stop the enzyme activity, then cool. Cold solution is added with $0.5 \mathrm{~mL}$ distilled water until the solution volume becomes $1 \mathrm{~mL}$. Substrate control was made without enzymes, while control of enzymes was made without starch substrates. Blanks are made without enzymes and substrates. The sample was tested according to the SomogiNelson method, 1941). One unit of enzyme activity is equivalent to $1 \mathrm{mg}$ of reducing sugar per $\mathrm{mL}$ formed under the above conditions.

\section{The measurement of protein enzyme glukoamilase (Phillip Hanson, 1981).}

The enzyme solution was measured using a spectrophotometer at a wavelength of $280 \mathrm{~nm}$.

\section{The hydrolysis of starch into sugars}

Tuber flour is weighed $0.5 \mathrm{~g}(10 \%), 0.75$ $(15 \%) \mathrm{g}$ and $1 \mathrm{~g}(20 \%)$, then put in a test tube, then $5 \mathrm{~mL}$ of distilled water is added, then shaken with vortex and gelatinized. The sample was put in a waterbath at $60^{\circ} \mathrm{C}$, then added the enzyme $0.5 \mathrm{~mL}(10 \%)$ and $0.75 \mathrm{~mL}$ (15\%). Incubation time is carried out for 24, 48 and 72 hours. Control is made with the same treatment, but without the addition of enzymes. The incubated samples were then heated for 2 minutes to stop the enzyme activity, then centrifuged at a speed of $7000 \mathrm{rpm}$ at $4^{\circ} \mathrm{C}$ for 10 minutes. The filtrate was taken and put into a tube and ready to be tested for reducing sugar using the same procedure as when measuring the standard D-glucose solution.

The same procedure was carried out for larger scale sugar production $(200 \mathrm{~mL})$ with the best composition from the research results $(20 \%$ enzyme concentration, $20 \%$ starch concentration and 72 hours incubation time). The temperature used was $60^{\circ} \mathrm{C}$ and room temperature. Sugar concentration is done by heating at a temperature of $100^{\circ} \mathrm{C}$ (5 times concentration)

\section{Measurement of levels of sweetness of sugar}

Sugar production samples were tested for sweetness using a refractometer

\section{Analysis of types of sugar in KLT}

Eluent n-butanol, glacial acetic acid, water prepared with a ratio of $2: 1: 1$, then put into the chamber. TLC plates are cut in size 10x10 $\mathrm{cm}$ with a start and finish distance of $1 \mathrm{~cm}$ each. The standard D-glucose, D-fructose, maltose, dextrin and lactose solutions were made $1000 \mathrm{ppm}$, then each sample and standard were dropped on the plate by $2 \mu \mathrm{L}$. Then the plate is inserted into the chamber and eluted until it reaches the finish line. The plate is dried with a hairdryer then sprayed with DPA solution 2 times, then dried in an oven $120^{\circ} \mathrm{C}$ for 10 minutes and the spot formed is observed.

\section{Results}

\section{Enzyme activity}

The enzyme activity obtained on each of them were 404,989 U / ml (red cassava peel) and 321,239 U / ml (white cassava peel). Protein levels were obtained $62.8 \mathrm{mg} / \mathrm{ml}$ (red cassava peel) and $60.54 \mathrm{mg} / \mathrm{ml}$ (white cassava peel) while reducing sugars were 10.719 $\mathrm{mg} / \mathrm{ml}$ and $9.156 \mathrm{mg} / \mathrm{ml}$ respectively (Table 1 ).

Table 1. The results of the measurement of enzyme activity, reducing sugar and protein from media of Cassava white peel and Cassava red peel

\begin{tabular}{lccc}
\hline \multicolumn{1}{c}{ Substrate } & $\begin{array}{c}\text { Enzyme } \\
\text { activity } \\
(\mathrm{U} / \mathrm{mL})\end{array}$ & $\begin{array}{c}\text { Reducing } \\
\text { sugar } \\
(\mathrm{mg} / \mathrm{mL})\end{array}$ & $\begin{array}{c}\text { Protein } \\
(\mathrm{mg} / \mathrm{m}\end{array}$ \\
\hline $\begin{array}{l}\text { Cassava } \\
\text { white peel }\end{array}$ & 321.239 & 9.156 & 60.54 \\
$\begin{array}{l}\text { Cassava red } \\
\text { peel }\end{array}$ & 404.989 & 10.719 & 62.8 \\
\hline
\end{tabular}

\section{Hydrolysis of starch into sugar}

Reducing sugar obtained at starch concentrations of $10 \%, 15 \%$ and $20 \%$ with $10 \%$ enzyme concentration for 72 hours incubation period, respectively are $62.26 \mathrm{mg} /$ $\mathrm{ml}, 68.72 \mathrm{mg} / \mathrm{ml}$ and $72.53 \mathrm{mg} / \mathrm{ml}$, while at $15 \%$ enzyme concentration obtained $63.83 \mathrm{mg}$ / $\mathrm{ml}, 82.67 \mathrm{mg} \mathrm{/} \mathrm{ml}$ and $84.61 \mathrm{mg} \mathrm{/} \mathrm{ml}$ 
respectively. The optimal conditions for hydrolysis of cassava starch are $20 \%$ starch concentration, $15 \%$ enzyme concentration and 72 hours incubation time.
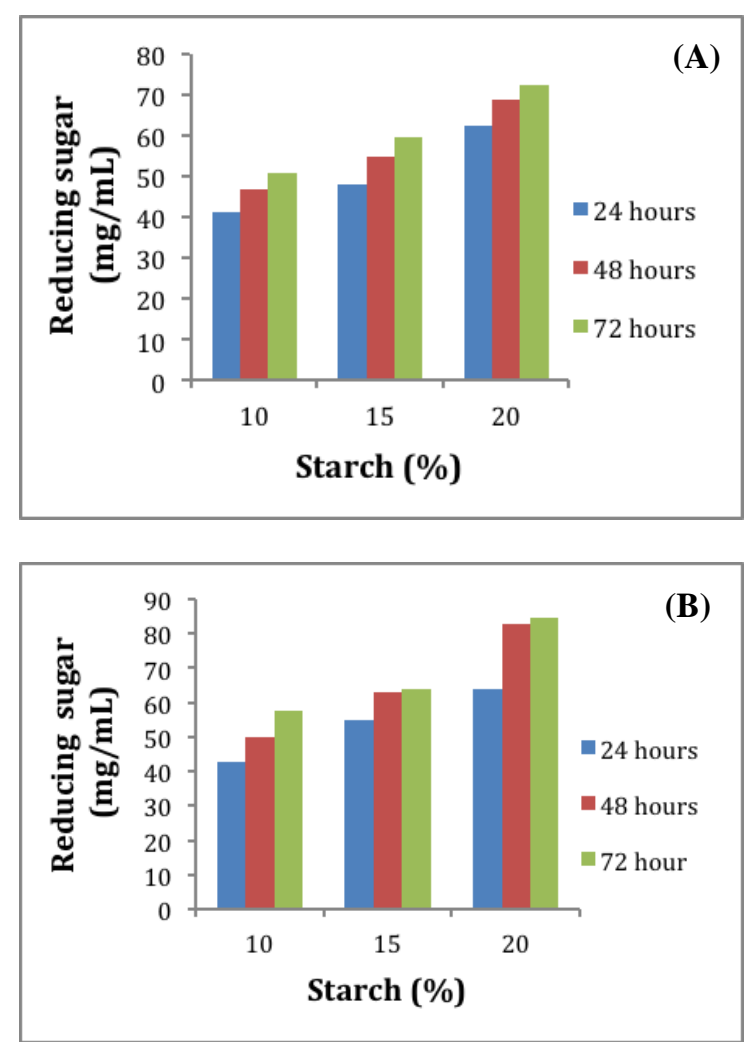

Figure 1. The results of the reducing sugar starch cassava by using enzyme concentration of $10 \%(\mathrm{~A})$ and $15 \%(\mathrm{~B})$.

The results of sweet potato starch hydrolysis (Figure 2), showed that the sugar, which obtained at 10\%, 15\%, 20\% starch concentrations for 72 hours of incubation period, each is $34.87 \mathrm{mg} / \mathrm{ml}, 49.85 \mathrm{mg} / \mathrm{ml}$ and $51.55 \mathrm{mg} / \mathrm{ml}(10 \%$ enzyme concentration) and $38.62 \mathrm{mg} / \mathrm{ml}, 51.50 \mathrm{mg} /$ $\mathrm{ml}$ and $52.49 \mathrm{mg} / \mathrm{ml}(15 \%$ enzyme concentration).

The results of the analysis of reducing sugars from Taro tubers which are based on starch concentrations of $10 \%, 15 \%$ and $20 \%$ respectively are $35.38 \mathrm{mg} / \mathrm{ml}, 40.10 \mathrm{mg} / \mathrm{ml}$ and $55.87 \mathrm{mg} / \mathrm{ml}$ (10\% enzyme) and 45.49 $\mathrm{mg} / \mathrm{ml}, 51.14 \mathrm{mg} / \mathrm{ml}$ and $61.39 \mathrm{mg} / \mathrm{ml}$ (15\% enzyme). The optimum conditions for hydrolysis of taro tubers were $15 \%$ enzyme concentration, $20 \%$ starch concentration and 72 hours incubation time.
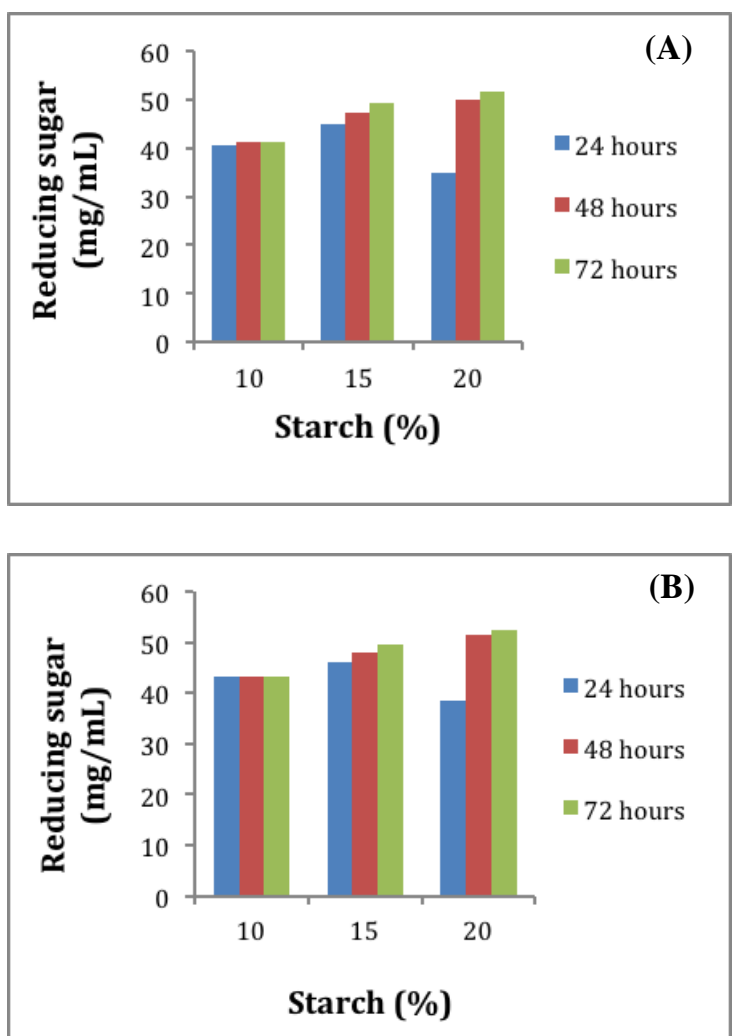

Figure 2. The results of the reducing sugar sweet potato starch using enzyme concentration of $10 \%$ (A) and $15 \%$ (B)

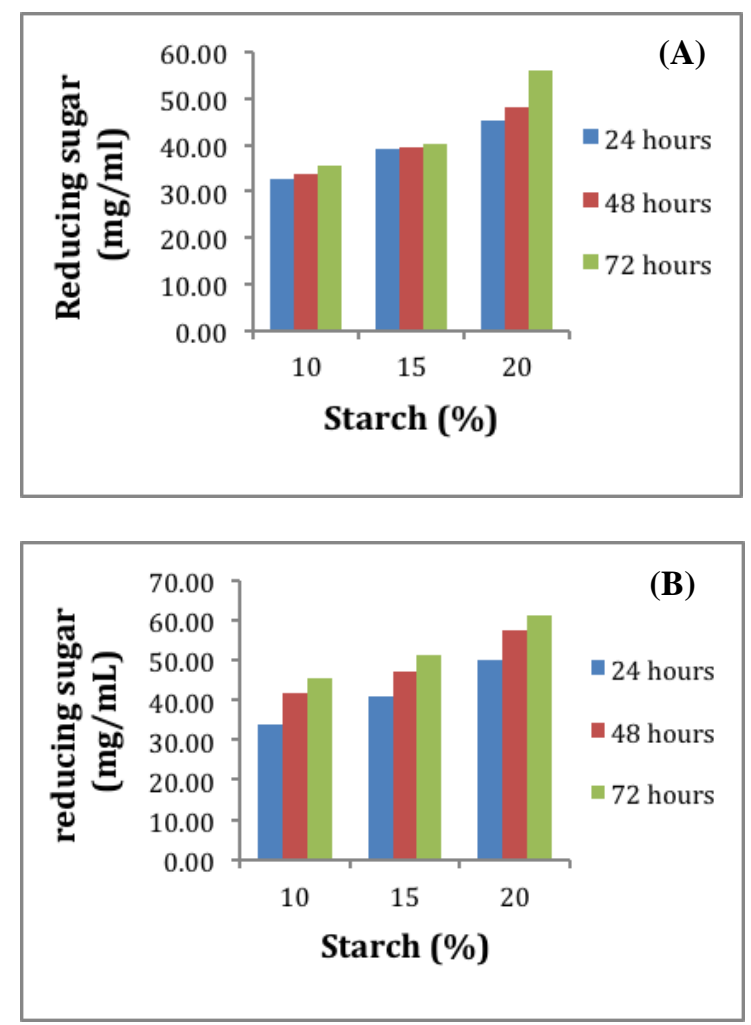

Figure 3. The results of the reducing sugar starch taro with enzyme concentration using $10 \%$ (A) and $15 \%$ (B). 
The hydrolysis pattern of starch flour into sugar (Figure 4), just like the pattern in sweet potato and cassava starch, only the sugar content produced is smaller. At 20\% starch concentration with $10 \%$ enzyme concentration, producing sugar as much as $27.13 \mathrm{mg} / \mathrm{ml}$, $27.64 \mathrm{mg} / \mathrm{ml}$ and $29.65 \mathrm{mg} / \mathrm{ml}$ while at $20 \%$ starch concentration and $15 \%$ enzyme concentration obtained results of $30.05 \mathrm{mg} /$ $\mathrm{ml}, 32.95 \mathrm{mg} / \mathrm{ml}$ and $42.87 \mathrm{mg} / \mathrm{ml}$ during a 72 hours incubation period.
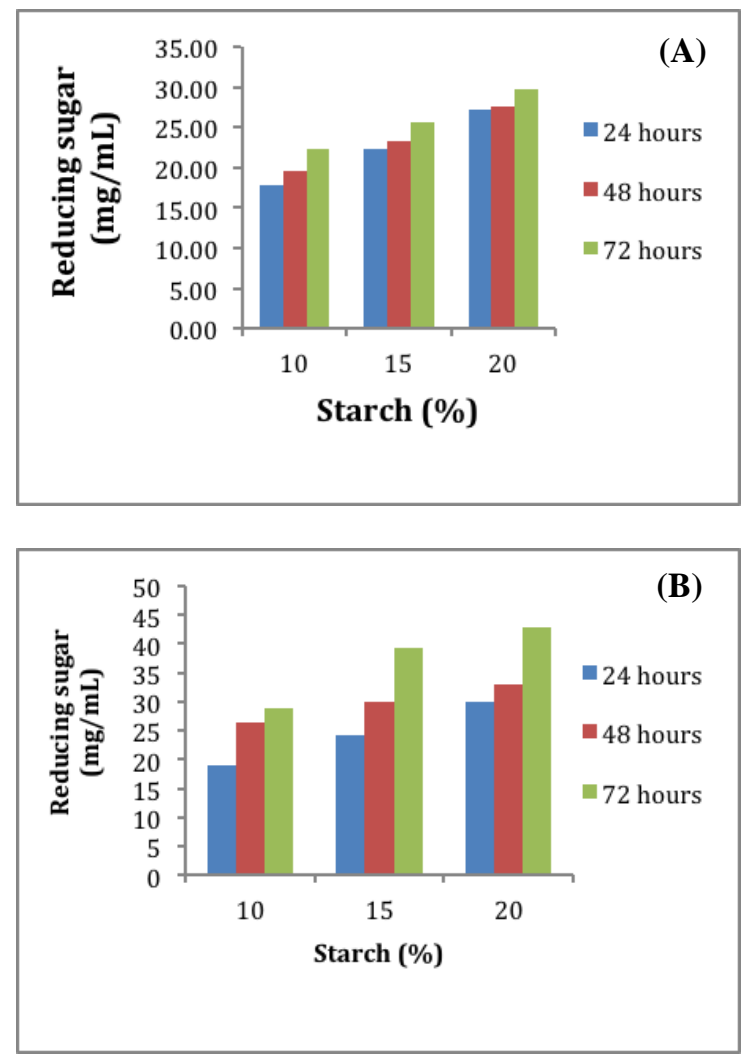

Figure 4. The results of the reducing sugars starch Cocoyam by using of enzyme concentration of $10 \%$ (A) and 15\% (B).

The best results sugar obtained from the four tubers were substrate concentration of $20 \%$, enzyme concentration of $15 \%$ and 72 hours incubation time at $60^{\circ} \mathrm{C}$ temperature.

Furthermore, liquid sugar is produced on a larger scale $(200 \mathrm{~mL})$ at $60^{\circ} \mathrm{C}$ and also at room temperature $\left(30^{\circ} \mathrm{C}\right)$, to get the best temperature conditions in producing liquid sugar. The sugar produced at $60^{\circ} \mathrm{C}$ gives better results than at $30^{\circ} \mathrm{C}$. The liquid sugar was concentrated to 10 times at $100^{\circ} \mathrm{C}$. Sugar production at $60^{\circ} \mathrm{C}$ can be seen in Figure 5

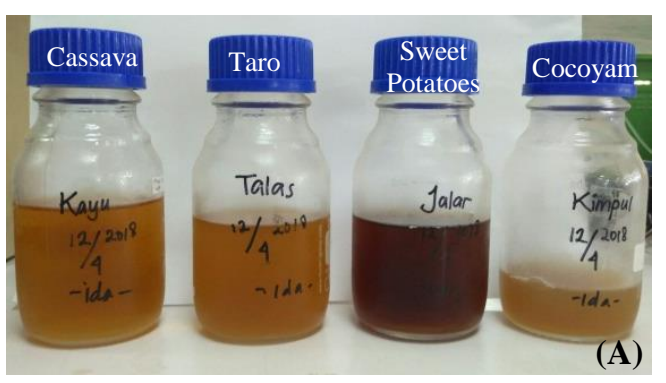

Reducing sugar produced from the four types of tubers (cassava, taro, sweet potatoes and Cocoyam) at optimum temperature were $101,380 \mathrm{mg} / \mathrm{mL}, 81,180 \mathrm{mg} / \mathrm{mL}, 55,929 \mathrm{mg}$ / $\mathrm{mL}, 47,874 \mathrm{mg} / \mathrm{mL}$, respectively. Meanwhile, hydrolysis carried out at room temperature results in lower reducing sugar levels than those carried out at $60^{\circ} \mathrm{C}$, except for taro tubers.

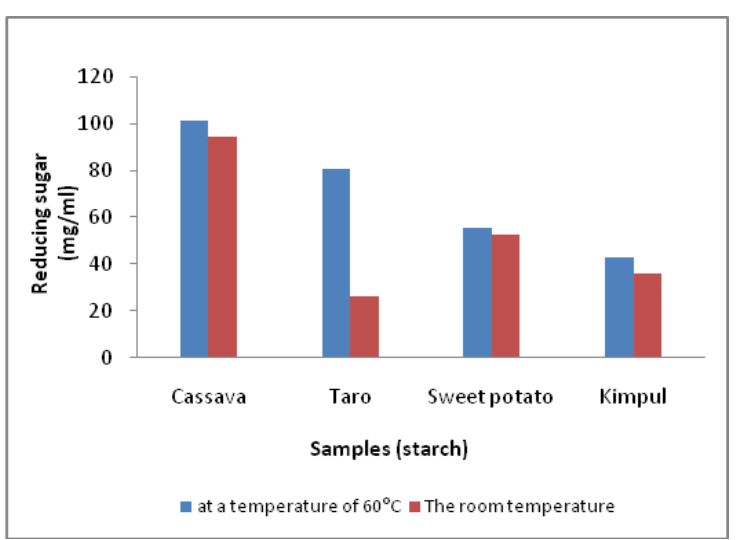

Figure 6. Reducing sugar levels from four different tubers on optimum condition (concentration of starch 20\% and concentration of enzyme $20 \%$ ) incubation at a temperature of $60^{\circ} \mathrm{C}$ and the room temperature for 72 hours.

The results of measuring the sweetness of sugar showed in Table 2. The degree of sweetness is shown in brix units. Brix is the amount of dissolved solids (g) every 100g of solution. The results of the analysis show that sugar produced from cassava has the highest degree of sweetness, while the tuber Cocoyam has the lowest yield.

The type of sugar produced by hydrolysis of tuber samples was analysed qualitatively using TLC method. The mobile phase used is a mixture of n-butanol: acetic acid: water with a ratio of 2: 1: 1 . The eluent is semi-polar with a polarity index of 5.8. The use of this eluent is because most monosaccharides or disaccharides are polar, so the sugar content in the sample will migrate and separate well. 
Qualitative testing of TLC sugar involves standard sugars (glucose, fructose, maltose, lactose, and dextrin) were using during analysis.

Table 2. Results of sugar sweetness measurement

\begin{tabular}{lcc}
\hline Samples & $\begin{array}{c}\text { The level of } \\
\text { sweetness } \\
\text { before } \\
\text { concentred } \\
\text { (Brix) }\end{array}$ & $\begin{array}{c}\text { Sweetness } \\
\text { after 5x } \\
\text { concentred } \\
\text { (Brix) }\end{array}$ \\
\hline Cassava & 14 & 80 \\
Taro tuber & 12 & 70 \\
Sweet pota & 9 & 60 \\
Cocoyam & 9 & 40 \\
\hline
\end{tabular}

This qualitative test is carried out by comparing the value of $\mathrm{Rf}$ produced by the spot in the sample and the standard. If the $\mathrm{Rf}$ value of the sample produced is the same as the standard Rf value, it indicates the content of the compound in the sample is the same with standard.

Table 3. Rf value standards and samples

\begin{tabular}{lcccc}
\hline Samples & Code & $\begin{array}{c}\text { The } \\
\text { amount } \\
\text { of stain }\end{array}$ & Rf & $\begin{array}{c}\text { Estimates } \\
\text { A } \\
\text { compound }\end{array}$ \\
\hline $\begin{array}{l}\text { Glucose- } \\
\text { standard }\end{array}$ & G & 1 & 0.65 & - \\
$\begin{array}{l}\text { Fructose- } \\
\text { standard }\end{array}$ & F & 1 & 0.66 & - \\
$\begin{array}{l}\text { Maltose- } \\
\text { standard }\end{array}$ & M & 1 & 0.48 & - \\
Lactose- & L & 1 & 0.56 & - \\
standard & & & & \\
Dextrin- & $\mathrm{D}$ & 1 & 0.58 & - \\
standard & & & & \\
Cassava & $\mathrm{Ka}$ & 1 & 0.48 & Maltose \\
& & 2 & 0.56 & Lactose \\
& & 3 & 0.64 & Glucose \\
Taro & $\mathrm{Ta}$ & 1 & 0.68 & - \\
& & 2 & 0.48 & Maltose \\
& & 3 & 0.65 & Lactose \\
& & 4 & 0.68 & - \\
Sweet & $\mathrm{Ja}$ & 1 & 0.51 & - \\
Potato & & 2 & 0.58 & Dextrin \\
& & 3 & 0.65 & Glucose \\
Cocoyam & $\mathrm{Ki}$ & 4 & 0.68 & - \\
& & & 0.66 & fructose \\
\hline
\end{tabular}

The results of TLC on fermented sugar samples from 4 tuber types are shown in Table 3. (Figure 7). Sugar cassava and taro sweet potato samples showed that there were 4 spots of sugar formed. Of the four spots, it is thought to contain maltose, lactose and glucose while one other spot is outside of the standard Rf value. Sweet potatoes also have 4 spots, with $\mathrm{Rf}$ values that are close to the standard dextrin and glucose, while the other two spots may be other types of sugar outside of standard sugars. Kimpul tuber only has 1 yellow spot known as fructose.

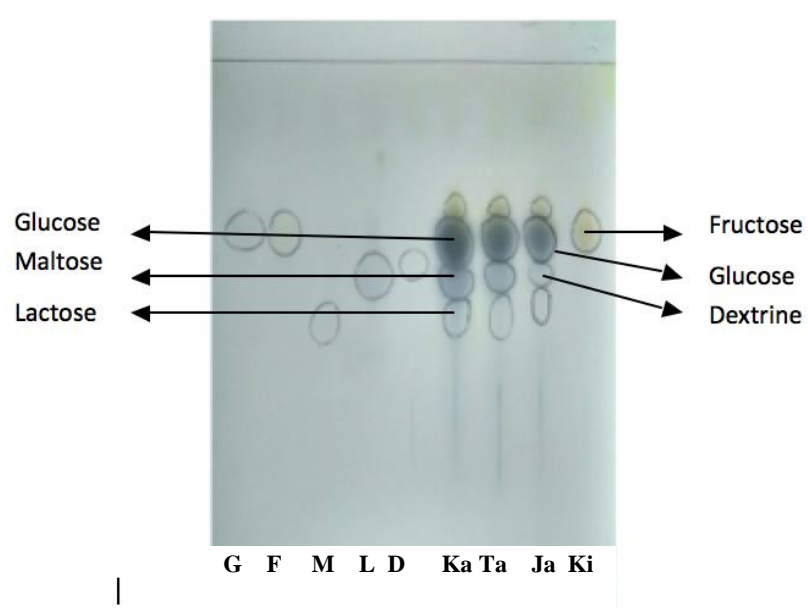

Figure 7. The result of qualitative analysis of sugars from starch hydrolysis of Manihot esculenta (Ka), Colocasia esculenta(Ta), Ipomoea batatas (Ja), Xanthosoma sagittifolium (Ki), Glucose (G), Fructose(F), Maltose(M), Lactose(L), Dextrine (D) in TLC.

\section{Discussion}

Making amylase enzymes complex from red and white cassava peel give different results, this is because the carbohydrate content in cassava peel is different as well as the mineral elements it contains. Observed from the media, the red cassava peel after sterilization appears to have white granules which are likely the starch which come out from the cassava peel and the peel structure itself is somewhat soft appearance, while white cassava peel seems to be driedThe humidity is one of the factors that support the growth of molds in the media to become more fertile. Compared to white cassava peel, media added with red cassava peel is slightly moist that could be one possibility of the different result in enzyme activity. The enzyme activity obtained on each of them was 404,989 U/ ml (red cassava peel and 321,239 $\mathrm{U} / \mathrm{ml}$ (white 
cassava peel). This result is consistent with a resultreported by Pe rwitasari et al. (2017) stated that the enzyme produced by Aspergillus awamori KT-11 using cassava peel substrate produces enzyme activity around at $300-400 \mathrm{U} / \mathrm{mL}$.

Red cassava peel media gives higher enzyme activity results than white cassava peel. This is possible because the starch and mineral content of red cassava peel is higher compared to white cassava peel. The results of this study provide an information that cassava peel contains a lot of carbohydrates so that cassava peels can be used as a medium for producing the enzymes. This is reinforced by Grace (1977) stated that the carbohydrate content of cassava peels is about $50 \%$ of the carbohydrate content of the tuber parts, as well as Richana (2013) reported that starch content in cassava peel was between $44-59 \%$. The application of enzymes to tuber flour media usisng enzyme extracts which is obtained from the medium of red cassava skin because of the enzyme activities of this biomaterial is higher (404.989 Unit).

In this study, 4 types of tubers starch were used namely cassava, sweet potato, taro, and cocoyam flour. As already known, starch will be broken down into sugar due to the action of glucoamylase or amylase.. The hydrolysis process is carried out for 72 hours at $60^{\circ} \mathrm{C}$. The results of reducing sugar levels for cassava samples (Figure 1) obtained a linear relationship between substrate concentration, enzyme concentration, incubation time, and reducing sugar content. The higher the substrate concentration, the higher the reducing sugar content can be produced as a result of the more starch can be hydrolyzed. The greater the percentage of complex amylase enzymes added, the greater the reducing sugar content produced as a result of enzymatical digestion of starch at glycosidic bonds, hence increase its products. The longer the hydrolysis time of starch, the more the sugar level reduces. Longer contact time between enzymes and starch let enzymes to digest its substrate in their optimal activity.

Hydrolysis of sweet potato starch showed that increasing the starch concentration, enzyme concentration, and incubation time, can enhance the yield of sugar (Figure 2). Except for $15 \%$ and $20 \%$ starch concentrations, both enzymes were added $10 \%$ and $15 \%$ (incubation time 24 hours). This is because the gelatinization process, sweet potato at a concentration of $20 \%$ has the highest viscosity among the other tubers. This viscosity is influenced by the amylose content in the starch. According to Putri and Nisa (2015), sweet potatoes have greater amylose content among other tubers, which is around at $25 \%$. The higher the content of amylose in starch, the thicker the gelatinization starch is, the more difficult the enzyme to hydrolyze the starch. In addition, low sugar levels can be caused due to less optimal stirring, so that the enzyme is not perfect to carry out the hydrolysis process of the starch.

The reducing sugar content produced from hydrolysis of taro tuber starch (Figure 3) is also directly proportional to the concentration of enzyme, substrate concentration and incubation time. The more enzyme concentration, substrate concentration, and the longer the incubation, the higher the sugar content can be obtained. This result shows that the higher the concentration of the enzyme, the more substrate that can be hydrolyzed so that the simple sugars as the final product also increase. The longer the incubation is carried out, the more substrates that can be hydrolyzed by enzymes and produce the reducing sugars. The optimum conditions for hydrolysis of taro tubers were $15 \%$ enzyme concentration, $20 \%$ starch concentration and 72 hours incubation time. The reducing sugar content obtained is $61,389 \mathrm{mg} / \mathrm{mL}$. Reducing sugar produced by ta starch as is lower than cassava starch. This is likely due to the different in the starch content. According to the reports, cassava starch content is $80 \%$ (El-Sharkawy 2012) and taro is between $70-80 \%$ (Kaushal et al., 2015).

The hydrolysis pattern of starch flour into sugar (Figure 4), same as the pattern in sweet potato and cassava starch, only the sugar content produced is smaller at 20\% starch concentration with $10 \%$ enzyme concentration, producing sugar as much as $27.13 \mathrm{mg} / \mathrm{ml}$, $27.64 \mathrm{mg} / \mathrm{ml}$ and $29.65 \mathrm{mg} / \mathrm{ml}$ while at $20 \%$ starch concentration and $15 \%$ enzyme concentration obtained results of $30.05 \mathrm{mg} /$ $\mathrm{ml}, 32.95 \mathrm{mg} / \mathrm{ml}$ and $42.87 \mathrm{mg} / \mathrm{ml}$. The gelatinization process of Cocoyam starch is rather difficult because it is thick so the possibility of starch hydrolysis process by enzymes does not decompose completely. According to Falade \& Okafor (2013) report that starch contained in the capsule is $75.5 \%$ carbohydrates, actually the starch content is 
quite high but because of the possibility of high amylose content that the gelatinization process of Cocoyam starch becomes difficult and the hydrolysis process becomes less perfect. Starch hydrolysis in all four tuber samples showed that the enzyme reaction that occurred still had not reached equilibrium. This is indicated by the still increasing levels of reducing sugars to the optimum state, so there is still a possibility that the reducing sugar levels will continue to rise if the enzyme concentration and incubation time are increased to reach a balanced state.

The results of the hydrolysis of the four samples have different colors. The color of the sugar produced is yellow to brownish yellow. The yellow color formed can be produced by the content of beta-carotene in the tuber sample. According to Islam et al., (2015), sweet potatoes have the highest content of beta-carotene among other tuber samples, so the yellow color produced is more concentrated. According to Triyono (2008), the yellow color can also be caused by the caramelization process. Caramelization is a reaction of changes that occur in compounds such as reducing sugar when heated at high temperatures to produce a brownish yellow color. The color produced has met SNI quality requirements 01-2978-1992 regarding glucose syrup which is colorless to yellow, except for the results of hydrolysis of sweet potatoes where the color produced is still too brown.

Analysis of reducing sugars on a large scale (Figure 6) yields higher values than hydrolysis using a tube. This is because the container used is larger (Erlenmeyer) which has a larger surface area so that the enzyme will be more easily spread evenly throughout all parts of the flour. In addition, the enzyme used has higher activity $(404,983 \mathrm{U} / \mathrm{mL}$ ), while the enzyme used before is only $321,233 \mathrm{U} / \mathrm{mL}$, so the hydrolysis results will be much better. Meanwhile, hydrolysis carried out at room temperature results in lower reducing sugar levels than those carried out at $60^{\circ} \mathrm{C}$, but not much different, except for taro tubers. This is because the amylase enzyme can work optimally at $60^{\circ} \mathrm{C}$ so that the hydrolysis process at room temperature does not work optimally.

The degree of sweetness is shown in brix units. Brix is the number of dissolved solids (g) every $100 \mathrm{~g}$ of solution. The results of the analysis show that cassava has the highest degree of sweetness, while the tuber has the lowest yield. This is because cassava has the highest starch content of around 83\% (Mustafa 2015), while the amylose in the tuberous tuber starch is $35.34 \%$, two times greater than amylose of cassava (Warkoyo et al. 2014). The higher the starch content in the tuber, the more reducing sugar produced from hydrolysis, so that the degree of sweetness is also higher. The sweetness level of the sugar that is concentrated is greater than that of unconcentrated samples. This result shows that the concentration process can increase the degree of sweetness of the sugar

Qualitative testing of sugar using TLC involves standard sugars, especially reducing sugars, namely glucose, fructose, maltose, lactose, and dextrin. According to Ristyoningsih (2011), starch hydrolysis by the $\alpha$-amylase enzyme will produce glucose and maltose, while $\beta$-amylase produces maltose and dextrin, while glucoamylase produces glucose so that the standard solution used is sufficient to represent the type of sugar hydrolyzed by the enzyme used (Figure 7).

The results of TLC obtained were in accordance with reducing the sugar content of each sample of the tuber. Cassava has the highest starch content and reducing sugar levels. This is indicated by the results of TLC obtained by having the most higher sugar compounds compared to other tubers. In addition, the spot color produced is estimated to be the most concentrated glucose compound among the others. This shows high glucose levels in the sample. It is different from the Cocoyam tuber, where the tuber has the smallest starch content and reducing sugar content which is characterized by the results of TLC which is only one spot and is thought to be a fructose compound.

\section{Conclusion}

Cassava peel can be used for the production of complex amylase enzymes with high enzyme activity. Sugar can be produced optimally from tubers, with $20 \%$ substrate concentration, $15 \%$ enzyme concentration and 72 hours incubation time. The reducing sugar content produced from the highest to the lowest is cassava, taro sweet potato, sweet potato, sweet potato tuber. The results of TLC show that cassava and taro tuber contain 
maltose, lactose, and glucose, sweet potatoes contains glucose and dextrin and Cocoyam tubers contain fructose.

\section{References}

Al-Kayyis, H., Susanti H. (2016). Comparison of the Somogyi-Nelson and Anthrone-Sulfate Methods in Determination of Reducing Sugar Levels in Cilembu Bulbs (Ipomea Batatas L.). Journal of Pharmacy Science and Community, 13(2), 81-89.

Ambarsari, I., Sarjana., \& Choliq A. (2009). Recommendations in Determining Standard Quality of Sweet Potato Flour. Standardization Journal, 11(3), 212-21.

El-Sharkawy, M. (2012). Stress-tolerant cassava: The role of integrative ecophysiology-breeding research in crop improvement. Journal of Soil Science, 2, 162-186.

Falade, O., \& Okafor, C. (2013). Physicochemical properties of five cocoyam (Colocasia esculenta and Xanthosoma sagittifolium) starches. Journal of Food Hydrocolloids. 30, 173-181.

Hanson, R.S., \& Philips, J.A.,(1981). Manual of methods for general bacteriology. American Society for Microbiol. Washington DC. p.359360

Husna., Novita., \& Rohaya, S. (2013). The anthocyanin content and antioxidant activity of fresh purple sweet potato and its processed products. Agritech Journal.33(3), 296-302.

Islam ,S.N., Nusrat ,T., Begum ,P., Ahsan ,M. 2016. Carotenoids and $\beta$-carotene in orange fleshed sweet potato: A possible solution to vitamin A deficiency. Food Chem.199, 628631.

Johnson, R., \& Padmaja, G. (2013). Comparative studies on the production of glucose and high fructose syrup from tubers starches. International Research Journal of Biology Sciences., 2(10), 68-75.

Kaushal, P., Kumar, V., \& Sharma, H. (2015). Utilization of taro (Colocasia esculenta): a review. Journal of Food Science and Technolog52(1), 27-40

Madara, D.W.Samaranayake., Aruma, B.J.C.G. De Silva.,Warna kulasuriya, R.D. Fernando., Kutadeni, V.T.Gunawardhane., and Herath Mudiyansilage, T. Herath. 2017. Optimization of liquefaction and saccharification times for laboratory scale production of glucose syrup from cassava starch and scalling up process of optimized conditons of pilot scale. Research journal of chemical sciences, 7(7), 1-5.

Mahmudatussa'adah, A. 2014. Chemical composition of Cilembu swet potato (Ipomoea batatas L) at various storge time as raw material of liquid sugar. Food, 23(1), 53-64.
Mensah, E.O., Ibok, O., Ellis, W.O, and Carey, E.E. 2016. Thermal Stability of -Amylase Activity and Sugar Profile of Sweet- Potato Varieties during Processing. Journal of Nutrition \& Food Sciences, 6(4), 1-5

Ministry of Agriculture. (2015). Strategic Plan of the Ministry of Agriculture 2015-2019. Jakarta (ID): Ministry of Agriculture.

Mustofa. 2015. Analysis of the process of making cassava starch (tapioca) based on mass balance. Agrointech, 9(2), 127-133

Nangin, D., \& Sutrisno, A. (2015). Amylase enzyme breaking down raw starch from microbes: literature review. Food Journal and Agroindustry,3(3), 1032-1039.

National Standardization Agency. (1992). SNI 012978-1992 concerning Glucose Syrup. Jakarta (ID): National Standardization Agency.

Nelson, N. (1941). A Photometric adaptation of the Somogy method for the determination of glucose. J. Biol. Chem., 153, 375-380

Permatasari, A.R., F. Sulistiani. 2015. Making liquid sugar from cassava starch by using enzymatic hydrolysis. Jornal Science and Technology, 11(2), 9-14.

Perwitasari, U., Nuryati., \& Melliawati, R., \& Yopi. (2017). Glucoamylase production by Aspergillus awamori KT-11 in solid-state fermentation using cassava peel as substrate. Journal of Annales Bogorienses, 21(1), 21-28.

Putra, K. A. W., Hartiati, A., Gunam, I. B. W..2015. Effect of temperature and concentration of the enzyme amiloglucosidase on the saccharification process on the production of liquid sugar of sweet potato starch (Colocasia esculenta). Journal of Agro-Industry Engineering and Management, 3(2), 130-139.

Putri, A M., Nisa, F. C. (2015). Modification of White Sweet Potato (Ipomoea batatas L.) Starch with Amylomaltase Enzyme Produces Thermoreversible Starch : A Review. Journal Food and Agroindustry V 3(2),749-755.

Rejeki, F.S., Puspitasari, D, dan Wedowati, E. R. 2017. The competitive advantage of kimpul liquid sugar. Journal of Research and Technology, 3(1), 46-53.

RichanaNur. 2013. Know the potential of cassava \& sweet potatoes.Nuansacendikia. Bandung

Risnoyatiningsih, Sri. 2011. Hydrolysis of starch Saccharides from sweet potatoes using enzyme. UPN Veteran East Java: J. Chem. Engineering Vol.5(2):417-424.

Robi'a ., A. Sutrisno. 2015. Characteristics of glucose syrup from purple sweet potato flour (Study of liquidation temperature and $\alpha$-amylase concentration) literature review. Journal of Food and Agro-Industry, 3(4), 1531-1537.

Safitri, A. (2014). Prebiotic production (Manooligosaccharide) from Porang Bulbs using Mananase BF 3.10 Streptomyces 
violascens Original Indonesian [Thesis]. Bogor (ID): Bogor Agricultural University.

Sutamihardja, RTM., Srikandi., Herdiani.D. P. 2015. Hydrolysis of chloride acid starch from cassava starch (Manihot esculenta Crantz) in making liquid sugar. Journal of Natural Sciences, University of Nusa Bangsa, 5(1), 8391

Warkoyo, W., Rahardjo, B.,, Djagal Wiseso Marseno,D.W.,, Karyadi, J.N.W. 2014.
Physical, Mechanical and Barrier Properties of Xanthosoma sagittifolium Starch-Based Edible Film Incorporated with Potassium Sorbate. Agritech ,34(1), 1-10.

Wei, S,,Lu G,,Cao, H. (2017). Effects of cooking methods on starch and sugar composition of sweet potato storage roots.PLoS ONE 12(8): e0182604.https://doi.org/10.1371/journal.pone.0 182604 